\title{
Bencana dan Tindakan Kepedulian Sosial dalam Keberagamaan: Studi Komparasi Kitab Suci al-Qur'an dan Alkitab
}

\author{
Abdul Qadri* \\ UIN Sunan Kalijaga Yogyakarta, Indonesia \\ Email: 19205010014@student.uin-suka.ac.id
}

\begin{abstract}
Indonesia is a country with a high potential for disaster threat, from BNPB (National Disaster Management Agency) data until September 3, 2020, nearly 4 million people died and 637 religious facilities were damaged. However, the enthusiasm of caring for its people, including disaster victims, Indonesia is included in the top 10 categories of the most generous countries in the world. On the other hand, the disaster in the two holy books of the majority of religions; Islam and Christianity tell a lot about the catastrophic events of the past people that were befallen those who disobeyed God. However, all the disastrous events that occurred were also experienced by those who obey God. For this reason, this article focuses on disasters as a phenomenon in the perspective of the Koran and the Bible, as well as how both of them respond to continuous and recent disaster events that seek to find a foundation and a common ground for both in responding to disaster phenomena in religious reality. This study uses a descriptivecomparative analysis method of the Qur'an and the Bible. This paper finds that (1) al-Qur'an and the Bible at least agree with the concept of disaster as God's will which is also related to human activity. (2) The response to disasters in the two books is similar in several ways, it's just that in the Bible disaster is sometimes interpreted as a sign of God's "presence" in the presence of humans. And finally (3), the two books explicitly provide messages of social concern from disaster events, on the basis of humanitarian brotherhood (ukhuwah insaniyah) or love for all mankind, without differences in race, culture, ethnicity, religion to the nations. So that a disaster event is a momentum for cooperation in a mission of mutual social concern, as well as to create and strengthen peace and harmony together.
\end{abstract}

Keywords: al-Qur'an; Bible; Disaster; Social Concren.

\begin{abstract}
Abstrak
Indonesia adalah negara dengan potensi ancaman bencana yang tinggi, dari data BNPB (Badan Nasional Penanggulangan Bencana) sampai 3 september 2020 hampir 4 juta korban jiwa dan 637 fasilitas peribadatan rusak. Namun, antusiasme kepedulian masyarakatnya, termasuk pada korban bencana, Indonesia masuk dalam 10 besar katagori negara-negara paling dermawan didunia. Disisi lain, bencana dalam dua kitab suci agama mayoritas; Islam dan Kristen banyak menceritakan peristiwa-peristiwa bencana umat terdahulu yang ditimpakan kepada mereka yang durhaka kepada Tuhan. Akan tetapi seluruh peristiwa bencana yang terjadi ternyata juga dialami oleh mereka yang taat kepada tuhan. Untuk itu artikel ini, memfokuskan bencana sebagai sebuah fenomena dalam perspektif al-Qur'an dan Alkitab, serta bagaimana keduanya merespon peristiwa bencana yang terus-menerus terjadi dan terakhir berupaya mencari landasan dan sekaligus titik temu keduanya dalam menyikapi fenomena bencana dalam realitas keberagamaan. Penelitian ini menggunakan metode deskriptif-analisis komparatif terhadap alQur'an dan Alkitab. Tulisan ini, menemukan bahwa (1) al-Qur'an dan Alkitab setidaknya senada berbicara konsep bencana sebagai kehendak tuhan yang juga terkait dengan ulah manusia. (2) Respon terhadap bencana dalam kedua kitab itu dalam beberapa hal ada kesamaan, hanya saja dalam Alkitab bencana terkadang dimaknainya sebagai tanda "kehadiran" Tuhan ditengan manusia. Dan terakhir (3), kedua kitab tersebut secara tegas memberikan pesan kepedulian sosial dari peristiwa bencana, atas dasar persaudaraan sekemanusiaan (ukhuwah insaniyah) atau Cinta Kasih pada seluruh umat manusia, tanpa perbedaan ras, budaya, suku, agama hingga bangsa-bangsa. Sehingga peristiwa bencana adalah momentum kerjasama dalam misi kepedulian sosial bersama, sekaligus untuk mewujudkan dan mempererat kedamaian dan kerukunan bersama.
\end{abstract}

Kata Kunci: Alkitab; al-Qur'an; Bencana; Kepedulian Sosial. 
Khazanah Theologia, Vol. 3 No. 2 (2021): 105-116

Bencana dan Tindakan Kepedulian Sosial dalam Keberagamaan: Studi Komparasi Kitab Suci al-Qur'an dan Alkitab

Abdul Qadri

\section{PENDAHULUAN}

Sepanjang tahun ini hingga 3 september 2020, Indonesia berdasarkan data dari BNPB (Badan Nasional Penanggulangan Bencana) telah terjadi 1.944 peristiwa bencana alam dan non-alam. Hampir 4 juta jiwa korban yang menderita dan mengungsi, serta 637 fasilitas peribadatan rusak dari dampak bencana alam, dan 184.268 jiwa terkonfirmasi Covid 19. Dan lebih dari 8.000 korban meinggal dunia (Ariansyah, 2020.). Berhubungan dengan agama, peristiwa-peristiwa bencana yang kerap terjadi itu tidak melihat identitas agama, kualitas ketaatan, atau status sosial individu, memiliki kemungkinan yang sama terdampak bencana. Namun teks-teks agama seperti Islam dan Kristen menceritakan sekian peristiwa bencana yang dulu terjadi, ditimpakan kepada mereka yang durhaka dan tidak kepada yang taat seperti saat ini.

Cukup menggembirakan, menurut laporan CAF World Giving Index, Indonesia dalam sekala 10 tahunan (2009-2018) menempati posisi ke-10 sebagai negara paling dermawan melalui tiga indikator yakni; mendonasikan uang untuk kegiatan amal, menolong orang asing, menyediakan waktu untuk kegiatan sosial (sukarelawan). Bahkan untuk pertama kalinya berada diposisi teratas di tahun 2018 dalam sekala tahunan dengan skor 59\% dari 36\% dan posisi ke-50 ditahun 2010 (CAF, 2019). Namun kedermawanan atau kepedulian sosial dalam kontek pasca bencana tidak jarang mengalami permasalahan ditengah pluralitas agama di Indonesia, termasuk kepentingan "egoisme" agama melalui kegiatan-kegiatan kemanusiaan itu, ditambah provokasi media masa (Humaedi, 2015, hlm. 212).

Sejauh ini, beberapa penelitian tentang bencana dan agama lebih banyak berbicara problem teologis terkait campur tangan Tuhan dan bencana, dengan sudut pandang agama masing-masing (Hidayat, 2016; Mustaqim, 2015, hlm. 81-88; Objantoro, 2016; Tefbana \& Rantung, 2020, hlm. 72-88; Yulianti, 2016, hlm. 158-169). Penelitian lainnya adalah mengenai hubungan religiositas dan bencana, bahwa bencana bisa meningkatkan religiositas yaitu terjadi peningkatan pelaksanaan ibadah-ibadah ritual dan juga sosial kemasyarakatan, serta keselarasan dengan alam (Darmawan, Miharja, Waluyajati, \& Isnaeniah, 2020; Suprapto \& Huda, 2020). Selain itu juga, terdapat penelitian yang membandingkan agama Islam dan Buddha (Munawaroh, 2011) atau antara agama dan budaya (I. Gusti Agung Paramita, 2018; Muhlis, 2012). Adapun penelitian terkait bencana dalam dua agama samawi yakni Islam dan Kristen tidak ditemukan, terlebih kontribusinya dalam menyikapi dampak sosial dari peristiwa bencana dalam kehidupan plural. Untuk itu diskusi ini menemukan relevansinya, terlebih untuk menemukan landasan teoritis terkait kontruksi umat beragama dalam menghadapi peristiwa-peristiwa bencana, sebagai sesama makhluk tuhan.

Melalui tulisan ini, berupanya melihat ontologis bencana (alam atau non-alam) dalam teks-teks kitab suci agama-agama, khususnya Islam dan Kristen. Setiap umat manusia tidak terlepas dari problem life, termasuk yang bersifat umum yakni bencana seperti gempa bumi, pandemi dan lainnya yang samasama ikut dirasai oleh seluruh umat beragama. Untuk itu, tulisan ini juga menelusuri sikap dan posisi agama-agama tersebut dalam menghadapi sebuah bencana bagi umatnya. Akhir-akhir ini manusia modern dengan kehebatan sains dan teknologi-nya, (tidak lebih hanya melakukan tindakan "perlawanan" terhadap bencana) yang melahirkan sekularisme, kekhawatiran akut dan hingga berakibat sikap apatisme. Di sisi lain, dengan prilaku pro-sosialnya (kepedulian sosial) justru menimbulkan sikap individualistik, materialistik dan kepentingan sendiri. Untuk itu, juga berupaya mencari landasannya dan sekaligus titik temu agama Islam dan Kristen dalam menyikapi fenomena bencana dalam realitas keberagamaan. Sebab dalam kaitan antara agama dan bencana, setidak tiga hal yang diasumsikan: Pertama, bahwa bencana yang terjadi tidak serta merta sebagai hukuman tuhan, lantas kemudian pasrah. Kedua, bahwa bencana yang terjadi seharusnya memiliki dimensi kepedulian dan rasa sosial yang tinggi. 
Khazanah Theologia, Vol. 3 No. 1 (2021): 105-116

Bencana dan Tindakan Kepedulian Sosial dalam Keberagamaan: Studi Komparasi Kitab Suci al-Qur'an dan Alkitab

Abdul Qadri

Dan Ketiga, bahwa sejatinya setiap agama-agama tidak melarang bahkan mendorong hal tersebut, tanpa membedakan identitas agama dan tanpa kepentingan.

Bencana secara umum diartikan dalam Kamus Besar Indonesia sebagai sesuatu yang menyebabkan (menimbulkan) kesusahan, kerugian, atau penderitaan; kecelakaan; bahaya. Dalam bahasa Inggris diterjemahkan dengan disaster yakni an event causing great harm, damage, or suffering (suatu peristiwa yang menyebabkan bahaya, kerusakan, atau penderitaan)(Dictionary, 2015). Disaster secara etimologi berasal dari bahasa Yunanai kuno yang berasal dari dus (buruk) dan aster (bintang). Istilah ini mengacu pada fenomena astronomi, terkait kemunculan bintang-bintang yang bertanda buruk. Secara spesifik, dalam institusi BNPB (Badan Nasional Penaggulangan Bencana) sebagai lembaga pemerintah nonkementrian yang bertugas melakukan penanggulangan bencana, bencana adalah rangkaian peristiwa yang mengancam dan mengganggu kehidupan dan penghidupan masyarakat yang disebabkan, baik oleh faktor alam dan/atau faktor non-alam maupun faktor manusia sehingga mengakibatkan timbulnya korban jiwa manusia, kerusakan lingkungan, kerugian harta benda dan dampak psikologis (Ariansyah, 2020). Dari sini, bencana merupakan interpretasi manusia atas peristiwa-peristiwa destruktif yang merugikan mereka, itu artinya jika tidak dirasakan oleh manusia maka tidak disebut sebagai bencana, yakni sebatas peristiwa alam belaka. Untuk mempertegaskan penelitian ini, istilah bencana dari BNPB dipilih sebab lebih mencerminkan bencana sebagai sebuah fenomena atau peristiwa berskala besar yang terjadi dan dialami oleh siapapun dan kapanpun.

Dalam studi agama, setiap agama di dunia barangkali membicarakan tentang bencana dalam konteks Kemaha Tuaha-nan, dengan berbagai perbedaan keyakinan disetiap agama-agama tersebut. Misalnya, kaum Zoroaster menyakini bahwa bencana adalah sebuah keniscayaan dalam realitas ketuhanan, yakni Tuhan buruk (Ahriman) yang akan selalu menciptakan bencana sedangkan tuhan baik (Mazda) berusaha memberbaiki dan menciptakan kebaikan. Hampir mirip dalam Hindu yang mempercayai tiga konsep ketuhanan, yakni pencipta (Brahma), pemelihara (Wisnu) dan perusak (Siwa). Baginya, bencana itu selalu ada dan harus ada untuk menjaga hermonisasi atau keseimbangan alam (Arqom Kuswanjono, 2012, hlm. 295). Bagi umat Buddha, bencana tidak ada hubungannya dengan tuhan, itu hanya kerusakan alam oleh aktifitas manusia (karma) yang tidak menjaga seimbangan lima hukum alam; Utu Niyama, Bija Niyama, Kamma Niyama, Dhamma Niyama dan Citta Niyama (Munawaroh, 2011). Sedangkan dalam Konghucu, bencana dapat dipahami dari Ciong. Ciong dalam prinsip Feng Shui yakni pada saat unsur elemen alam dalam diri manusia saling bertentangan yang membentuk panah segitiga sehingga menimbulkan perpecahan dan sumber malapetaka dalam hidup manusia. Hal itu dikarenakan kurangya keseimbangan elemen tersebut, yakni elemen air, kayu, api, tanah dan logam yang seharusnya saling melengkapi. Dan dengan Ciswak sebagai ritual menolak bala dari Ciong tersebut (Wijaya, Azeharie, \& Pribadi, 2019, hlm. 543).

Termasuk juga, Agama-agama Abrahamik, seperti Islam, Yahudi dan Nasrani yang juga membicarakan bencana, bahkan mengabadikan peristiwa-peristiwa bencana yang pernah terjadi dimasa silam. Itu artinya, seluruh agama yang merespon bencana yang bersifat destruktif itu, memberikan pemahaman, motivasi, atau solusi dalam realitas sosial manusia sebagai korban. Tidak dapat dipungkiri, dengan perkebangan sains dan teknologi mempengaruhi pola pikir masyarakat modern dalam memahami bencana. Walaupun disadari atau tidak, keterbatasan manusia dan bencana yang terus terjadi (perennial) tetap akan dialami oleh umat manusia, terkadang membawa mereka kembali (mempercayai) kepada ajaran agama, mitos atau ritual tradisional seperti yang terjadi di Amerika dan Jepang sebagai negara kemajuan dan teknologi yang pesat (Mohammad Hasan 
Khazanah Theologia, Vol. 3 No. 2 (2021): 105-116

Bencana dan Tindakan Kepedulian Sosial dalam Keberagamaan: Studi Komparasi Kitab Suci al-Qur'an dan Alkitab

Abdul Qadri

Basri, Apriadi Ujiarso, \& Laily Hafidzah, 2012, hlm. 264). Itulah mengapa Mark Pelling mengatakan bahwa peristiwa bencan akan melahir kesadaran humanistik, solidaritas, eksistensial dan ketuhanan (Ichwan, 2012, hlm. 263). Berangkat dari ini, kepedulian sosial sebagai kesadaran humanistik sedikit diulas selanjutnya.

\section{Kepedulian Sosial}

Dalam Kamus Besar Bahasa Indonesia (KBBI), kepedulian terambil dari kata peduli yakni mengindahkan, memperhatikan, dan menghiraukan. Dan kepedulian sosial adalah sikap mengindahkan (memperhatikan) sesuatu yang terjadi dalam masyarakat (Pusat Bahasa (Indonesia), 2005). Menurut Darmiyati Zuchdi, kepedulian sosial merupakan sebuah sikap dan tindakan ingin memberi bantuan kepada yang membutuhkan (Zuchdi, 2011, hlm. 107). Dalam hal ini, kepedulian sosial dimaknai sikap memperhatikan permasalahan atau kesulitan orang disekitar yang terkena bencana untuk memberikan bantuan material atau non-material. Manusia dinamai makhluk sosial, sebab sifatnya bergaul dan berinteraksi satu sama lain, atau zoon politikon (hewan yang bermasyarakat) dalam istilah Aristoteles untuk membedangannya dengan hewan. Sifat itulah yang kemudian, membuat manusia salaing membutuhkan dan bergantung satu sama lain. Untuk itu, kepedulian satu sama lain (bermasyarakat) yakni kepedulian sosial, adalah keniscayaan dalam diri manusia sebagai makhluk sosial.

Lebih luas dalam hal itu, psikolog Alfred Adler mengistilahkannya dengan gemeinschaftsgefühl atau social interes dalam bahasa Inggris, yakni rasa bersosial, rasa berkomunikasi, rasa persatuan dengan semua umat manusia; secara tidak langsung menyatakan keanggotaan dalam komunitas sosial seluruh manusia. Ia mendefinisikan kepedulian sosial itu sebagai sikap keterhubungan dengan kemanusiaan pada umumnya, sebuah empati bagi setiap anggota komunitas manusia. Sehingga kepedulian sosial itu dimanifestasikan sebagai kerja sama dengan orang lain demi kemajuan sosial, bukan keunggulan pribadi semata (Marwing, 2016, hlm. 255). Dengan demikian, tidak semua tindakan-tindakan kepedulian sosial itu disebut sebagi kepedulian sosial bagi Adler, sebab ketiadaan rasa bersatu atau persamaan (empati) kepada yang diberi itu berakibat melahirkan kaum lemah (inferior) dan kaum unggul (superior). Dalam hal ini, Adler melakukan kritikan terhadap tren kepedulian sosial masyarakat modern, yang dimotivasi kepentingan individulis, kelompok, korporasi, hingga kepentingan politik. Misal dalam konteks kebencanaan, beberapa gerakan peduli atau filantropis mengalami persoalan ditengah masyarakat agama yang plural dan masyarakat yang menjunjung tinggi kebudaannya, terutama persoalan isu atau provokasi "kepentingan" agama tertentu, apakah itu bukan misi terselubung?. Untuk itu, setidaknnya sementara beberapa rambu yang ditawarkan dalam mewujudkan kepedulian sosial; Pertama, tidak melakukan penyebaran agama. Kedua, menjaga kewibawaan dan kesucian tempat sakral serta pemimpinnya. Ketiga, tidak menampilkan embel-embel agama. Keempat, tidak mengkhususkan sekelompok orang (Humaedi, 2015).

\section{METODE PENELITIAN}

Metode yang diterapkan dalam penelitian ini menggunakan deskripsif-analisis untuk menemukan landasan toritis terkait bencana dari agama Islam dan Kristen. Metode deskriptif analisis diupayakan untuk mendeskriptif objek penelitian melalui data-data literatur yang telah dikumpulkan. Untuk itu, penelitian ini masuk dalam katagori penelitian kepustakaan, yakni objek penelitiannya bersumber dari buku-buku, artikel dan lainnya yang berhubungan dengan arah penelitian yang diangkat (Suryadilaga, 2005, hlm. 153). Kemudian dua perspektif sekaligus yang 
Khazanah Theologia, Vol. 3 No. 1 (2021): 105-116

Bencana dan Tindakan Kepedulian Sosial dalam Keberagamaan:

Studi Komparasi Kitab Suci al-Qur'an dan Alkitab

Abdul Qadri

digunakan yakni agama Islam dan Kristen, maka penelitian ini termasuk penelitian komparatif. Metode komparasi digunakan untuk berusaha melihat aspek perbedaan dan persamaan dari dua atau lebih obyek pernelitian (Setiawan, 2018), sehingga akan dapat menemukan titik temu kedua agama tersebut.

\section{HASIL DAN PEMBAHASAN}

\section{Bencana dalam Perspektif al-Qur'an dan Alkitab}

Merujuk istilah bencana secara umum, setidaknya ada beberapa term yang lazim dalam kitab suci al-Qur'an, seperti mushibah, fitnah, bala', dengan perbedaan aksentuasi disetiap tempatnya (Mustaqim, 2015, hlm. 99-104). Peristiwa-peristiwa bencana yang kerap kali terjadi, itu menimbulkan kerusakan dan penderitaan di muka bumi yang mengganggun dan mengancam kelangsungan hidup manusia dan makhluk tuhan lainnya. Dalam kitab suci agama Islam, bencana itu kiranya dapat dipahami sebagai kerusakan sebagaimana yang disebutkan dalam Q.S. al-Rum 30: 41:

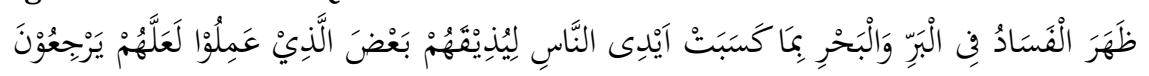

Telah tampak kerusakan di darat dan di laut disebabkan karena perbuatan tangan manusia; Allah menghendaki agar mereka merasakan sebagian dari (akibat) perbuatan mereka, agar mereka kembali (ke jalan yang benar).

Terdapat dua poin dalam ayat diatas, pertama bahwa kerusakan atau bencana yang terjadi di belahan dunia manapun itu disebabkan oleh ulah manusia. Manusia memiliki peran atas kerusakan yang terjadi baik di langit atau tanah, apakah itu disebabkan oleh prilaku manusia dengan alam atau kezaliman yang merajalela. Di ayat yang lain ditegaskan dalam Q.S. al-Syura 42: 30 :

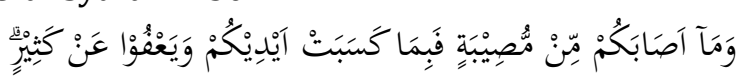

Dan musibah apa pun yang menimpa kamu adalah disebabkan oleh perbuatan tanganmu sendiri, dan Allah memaafkan banyak (dari kesalahan-kesalahanmu).

Kedua, bahwa Allah memang menghendaki dan dalam sepengetahuan-Nya dari itu semua, sebagaimana juga terdapat dalam Q.S. al-Taghabun 64:11:

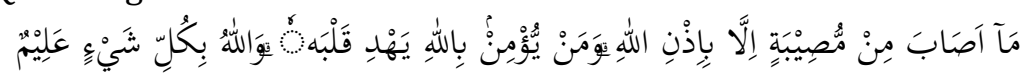

Tidak ada sesuatu musibah yang menimpa (seseorang), kecuali dengan izin Allah dan barangsiapa beriman kepada Allah, niscaya Allah akan memberi petunjuk kepada hatinya. Dan Allah Maha Mengetahui segala sesuatu.

Kehendak Allah itu diayat yang lain secara jelas, ternyata telah ditulis sebelumnya di Lauh alMahfudz, sebagaimana yang diterangkan dalam Q.S. al-Hadid 57:22:

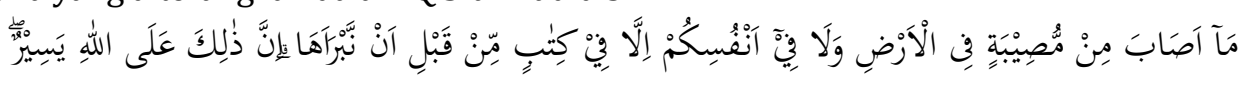

Setiap bencana yang menimpa di bumi dan yang menimpa dirimu sendiri, semuanya telah tertulis dalam Kitab (Lauh Mahfuzh) sebelum Kami mewujudkannya. Sungguh, yang demikian itu mudah bagi Allah.

Ada beberapa rangkain peristiwa bencana yang diabadikan dalam al-Qur'an, misalnya bencana alam seperti peristiwa bencana Banjir kaum Nabi Nuh (Q.S. al-Qamar 54: 11-14 "kronologinya disebutkan didalam ayat itu"), Suara Keras kaum Samud (Q.S. al-Haqqah 69:5), Angin Topan Dingin kaum 'Ad (Q.S. alHaqqah 69: 6-7), Gempa Bumi kaum Syu'ab (Q.S. al-'Ankabut 29: 37), Petir kaum Samud (Q.S. al-Zariat 51: 
Khazanah Theologia, Vol. 3 No. 2 (2021): 105-116

Bencana dan Tindakan Kepedulian Sosial dalam Keberagamaan:

Studi Komparasi Kitab Suci al-Qur'an dan Alkitab

Abdul Qadri

43-44), Penenggalan ke bumi kepada Qarun (Q.S. al-Qashshash 28:81) dan peristiwa-peristiwa bencana lainnya.

Sedangkan dalam Alkitab teologi bencana dimaknai sebagai kehendak Allah yang hadir dan merasakan penderitaan dari bencana tersebut (Yesaya. 63:9, 1 Petrus. 5:6-7), dari diri Yesus sebagai "Juruselamat" dalam mengatasi persoalan-persoalan tersebut (Siahaya, Siahaya, \& Rinukti, 2020, hlm. 147). Dan manusia juga ikut menyebabkan peristiwa bencana terjadi (Wahyu.11:18), sehingga Allah tidak bisa disalahkan (Amsal. 19:3) Beberapa kisah kehadiran Tuhan dalam penderitaan manusia, tertulis dalam Alkitab seperti Tuhan mengunjungi Abraham dalam wujud manusia di satu dari tiga orang yang mendatanginya di dekat pohon Tarbantin di Mamre, untuk memberikan janji-Nya meberikan anak (Ishak) dikemudian hari. (Kej. 18:1-15). Hingga dikaruniai anak bernama Ishak, Abraham dan Sara sebelumnya menderita karena tidak memiliki anak. Hal itu (kehadiran Tuhan dalam penderitaan) juga terjadi pada penderitaan-penderitaan dari bencana alam dan non-alam. Misalnya peristiwa bencana Gempa Bumi yang terjadi di masa Uzia, Raja Yehuda (Zakh.14:5, Ams. 1:1), Wabah penyakit Sampar yangg menimpa bangsa Israel (2 Samuel. 24:15), Barah yang menimpa Ayub, serta peristiwa-peristiwa bencana lainnya.

Peristiwa-peristiwa bencana yang tercatatan dalam Alkitab sebagai hukuman dari Allah itu hanya menimpa orang jahat dan menyelamatkan yang baik (Kejadian. 19:29-30) dan memberikan pringatan terlebih dulu sehingga akan diselamatkan jika mereka berubah (Kejadian. 7:1-5, Matius. 24:38-39). Hal itu berbeda dengan bencana yang terjadi sekarang, tanpa pengecualian seluruh manusia yang berada disekitar itu akan terdampak bencana. Untuk itu, Allah menyalurkan bantuan pada korban bencana dengan dua hal, peratama, melalui firman-firman penghibur korban bencan (Kejadian. 18:25, Mazmur. 46:1-2, Yaseya. 63:9, Yohanes 5:28-29, 1 Petrus. 5:6-7 dan Wahyu. 21:4). Kedua, melalui para penyembahnya (Yesaya. 61:1-2, Yohanes. 13:15)

\section{Respon al-Qur'an dan Alkitab terhadap Bencana}

Bencana dalam kitab suci al-Qur'an ditanggapi dengan beragam, antara lain: Petama sebagai murka atau azab Allah (Asparina \& Farhani, 2020). Bencana yang disebabkan oleh murka Allah itu hanya terjadi pada umat-umat Nabi terdahulu, seperti peristiwa bencana banjir Nabi Nuh. Namun atas permintaan Nabi Muhammad saw empat jenis azab Allah (Q.S. al-An'am: 65), dua diantaranya dari langit dan dari bumi tidak terjadi pada ummatnya. Walaupun demikian, kenyataannya peristiwa-peristiwa "azab" itu tetap terjadi seperti gempa bumi, sunami atau lainnya akan tetapi tidak sedahsyat umat terdahulu atau menurut al-Asqalani tidak membinasakan umatnya keseluruhan (al-Asqalani, t.t., hlm. 124-125). Kedua, peristiwa bencana dapat diangga sebagai ujian yang diberikan Allah kepada mereka yang tertimpa musibah (Mustaqim, 2015, hlm. 102) untuk mereka yang bersabar (Q.S. al-Baqarah 2:155) sehingga mereka tergolong memperoleh petunjuk (al-Muhtadun). Ketiga, sebagai bukti kekuasaan-Nya sebagaimana yang disitir dalam Q.S al-An'am: 65 agar dapat dipahami.

Bencana dalam Alkitab dimaknai dengan berbagai macam, diantaranya (Cakra, 2020, hlm. 5; Objantoro, 2016, hlm. 140): Pertama sebagai murka Allah, seperti peristiwa bencana Air Bah yang membinasakan seluruh makluk di bumi kecuali Nuh dan yang bersamanya (kej. 7: 21-24), atau wabah penyakit Sampar (Mazmur. 78:50). Kedua sebagai kuasa-Nya, bahwa alam dan segala isinya dibawah kekuasaannya, seperti: peristiwa bencana abangsa Israel yang mendapati air yang pahit setelah tibanya di Mara, dengannya Allah menggunakan sepotong kayu yang dilemparkan kedalam air sehingga manis dan dapat diminum (kel. 25:23-25) Dan Kisah Angin ribut yang diredakan (Mat. 8:23-26). Ketiga sebagai ujian, seperti Penderitaan Ayub berupa penyakit Barah yang busuk (Ayub 1). Bagi E. G. Singgih bahwa penderitaan Ayub sebgai ujian iman dengan wabah penyakit yang datang dari Iblis dan disetujui oleh 
Khazanah Theologia, Vol. 3 No. 1 (2021): 105-116

Bencana dan Tindakan Kepedulian Sosial dalam Keberagamaan: Studi Komparasi Kitab Suci al-Qur'an dan Alkitab

Abdul Qadri

Tuhan (Singgih, 1999, hlm. 266). Keempat sebagai tanda kehadiran-Nya, seperti tanda kehadiran Tuhan menemui dan berbincang bersama Musa dengan seluruh gunung Sinai berguncang hebat "Gempa Bumi" dan bunyian hebat sangkakala (Kel.19:18-19). Kelima sebagai tanda akhir zaman, seperti gempa bumi dahsyat, penyakit Sampar dan tanda-tanda dahsyat dari langit. (Luk. 21:11).

\section{Bencana dalam Keberagamaan}

Saat peristiwa bencana terjadi dampak sosial, psikologis dan ekonomi tentu dirasakan oleh korban bencana, tanpa memandang identitas agama, status soial atau suku, dimanapun dan kapanpun. Baik muslim atau kristiani memiliki kemungkinan yang sama, terlebih ketika mereka berada di daerah rawam bencana. Untuk itu, kepedulian sosial terhadap korban bencana harus terealisasikan, bahkan sejatinya agama tentu mendorong hal itu, sebab mereka adalah sama-sama makhluk tuhan.

Dalam kitab suci al-Qur'an ditegaskan bahwa seluruh umat manusia berasal dari ayah dan ibu yang satu (Q.S. al-A'raf: 27), disisi lain al-Qur'an mengakui eksistensi keragaman ras, suku, budaya, bangsa dan agama (Q.S. al-Hujurat: 13). Atas dua hal tersebut seluruh umat manusia satu sama lain dimuka bumi ini, terikat persaudaraan universal tanpa terkecuali. Prinsip persaudaraan itu kemudian dimaknai untuk berbuat baik kepada sekitar kita, sebagaimana secarat tegas disebutkan dalam Q.S. al-Nisa': 36.

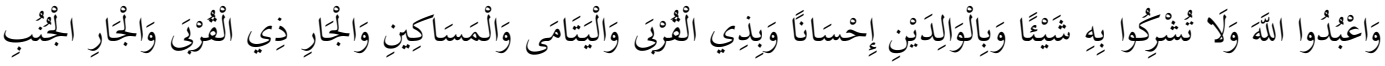

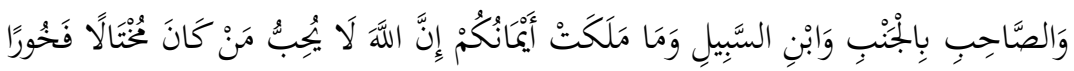

Sembahlah Allah dan janganlah kamu mempersekutukan-Nya dengan sesuatupun. Dan berbuat baiklah kepada dua orang ibu-bapa, karib-kerabat, anak-anak yatim, orang-orang miskin, tetangga yang dekat dan tetangga yang jauh, dan teman sejawat, ibnu sabil dan hamba sahayamu. Sesungguhnya Allah tidak menyukai orang-orang yang sombong dan membangga-banggakan diri.

Nauf al-Syami sebagaimana yang dinukil oleh al-Qurthubi dalam tafsirnya, ia mengomentari al-jar dzi al-qurba sebagai masyarakat Muslim dan al-jar al-junub sebagai masyarakat Yahudi dan Nasrani (AlQurtubi, 2006, hlm. 304). Semakna dengan itu, dalam Q.S. al-Maidah: 2 juga diperintahkan untuk saling berbuat baik, al-Mawardi mengatakan untuk saling berupaya dalam kebaikan sesama manusia sehingga akan menemukan kedamaan dan ketentraman. Al-Akhfasy juga menomentari bahwa perintah itu ditujukan kepada seluruh makhluk agar saling tolong menolong (Al-Qurtubi, 2006, hlm. 268). Tidak hanya itu, di banyak tempat al-Qur'an telah menyebutkan, seperti tidak mecari kesalahan orang lain, menggunjing mengolok-olok, saling mencela satu sama lain (Q.S. al-Hujurat: 12), berbuat baik dan berlaku adil (Q.S. al-Mumtahanah 60: 8), Ibnu 'Arabi sebagaimana yang dinukil oleh Quraish Shihab hakikat tuqsithu (berlaku adil) dalam ayat tersebut ialah memberi bagian hartamu untuk memelihara hubungan baik (Shihab, 2020, hlm. 89).

Sedangkan bagi umat kristiani, berperan aktif dalam bantuan sosial kepada korban bencana tanpa terkecuali adalah sebagai wujud ekspresi kasih Tuhan Yesus Kristus yang ada dalam kehidupan kita sebagai orang yang sudah dikasihi dan diselamatkan oleh-Nya, untuk mengasihi Allah dan sesama manusia (Matius 22:39), sebagai teladan-Nya (Yohanes 13:15). Dalam Yohanes 13:34-35 disebutkan bahwa:

Bahwa ini adalah perintah tuhan. Dengan mengasihi sesama orang akan tahu bahwa kita adalah murid-murid Tuhan Yesus." Karena hal itulah, melalui kasih Tuhan untuk seluruh umat manusia dengan mengorbankan hidup-Nya dalam Yesus Kristus.

Untuk itu, Gereja sebagai representatif kehadiran Allah di dunia sebagai pembawa damai bagi umat manusia, memiliki tanggung jawab sosial demi terwujudnya kedamaian umat manusia, teruntuk bagai 
Khazanah Theologia, Vol. 3 No. 2 (2021): 105-116

Bencana dan Tindakan Kepedulian Sosial dalam Keberagamaan: Studi Komparasi Kitab Suci al-Qur'an dan Alkitab

Abdul Qadri

korban bencana. Sebab Allah sangat memperhatikan orang tertindas yang butuh pertolongan, bahkan kepada mereka tidak layak menerima pertolongan (Ulangan. 10:17-19, 24:17-22, 26:11, Imamat. 19:3334, dan Mazmur. 103: 6)(Tefbana \& Rantung, 2020, hlm. 83). Sehingga peran gereja tersebut tidak hanya sekedar kepedulian sosial melainkan gerakan iman, fungsionalisasi dan aktualisasi karya penyelamatan Tuhan bagi dunia oleh gereja (Siahaya dkk., 2020). Untuk itu dilakukan berdoa sebagai ekspresi iman kepada Allah yang berdaulat atas seluruh ciptaan-Nya untuk mengampuni dan melewati peristiwa bencana tersebut, serta dengan kepedulian sosial melalui berbagai bantuan (Tefbana \& Rantung, 2020). Sepanjang sejarah, misalnya terkait bencana non alam (wabah) umat Kristiani berpartisifasi untuk mengorbanan dan mengabdian diri kepada selain dari agama Kristen (Tefbana \& Rantung, 2020, hlm. 83).

\section{Bencana dan Tindakan Kepedulian Sosial dalam Keberagamaan}

Satu hal terkait bencana dalam al-Qur'an yang tidak jauh berbeda dari Alkitab, keduanya menyebutkan bahwa bencana tidak akan terjadi tanpa izin Tuhan, dan juga atas prilaku manusia. Tentu hal tersebut tidak mengherankan sebab kedua agama tersebut termasuk juga Yahudi disebut Agama Abrahamik yang memiliki leluhur yang sama yakni Nabi Ibrahim sebutan dalam Islam, Abraham dalam Kristen dan Yahudi. Hanya saja perbedaan mendasar dari keduanya, dalam Islam ketentutan-ketentuan yang terjadi di muka bumi ini termasuk peristiwa bencana telah ditetapkan oleh Allah di Lauh al-Mahfudz. Sedangkan dalam Alkitab tidak (atau tidak disebutkan), bagi umat Kristiani keberadaan bencana juga ikut dirasakan oleh Tuhan melalui Yesus sebagai Juruselamat. Bentuk penyelamatan tersebut kemudian direpresentasikan atau diteladani oleh gereja. Sehingga kemudian, peran sosial menjadi keharusan bagi umat Kristiani untuk menyelamatkan umat manusia dari bencana, melalui bantuan matari atau nonmateri. Di kalimat terakhir, dalam Islam mengenal istilah persaudaraan sesama manusia (Ukhuwah Insaniya) untuk melakukan kegiatan-kegiatan sosial tersebut. Aksi dan gerakan kepedulian sosial keduanya sebagai refleksi dari keimanan masing-masing, tidak ada dalam kedua kitab suci tersebut mengajarkan sikap tidak peduli (indifferent) atau masa bodoh terhadap sekitarnya yang membutuhkan, bahkan kepada keyakinan yang berbeda dari mereka.

Sebagai agama samawi, Islam dan Kristen setidaknya memiliki titik temu antara lain, menyakini Adan dan Hawa sebagai manusia pertama. Sama halnya terkait konsep bencana, tidak ada perbedaan keduanya bahwa bencana adalah kehendak Tuhan yang berhubungan dengan prilaku umat manusia, dan seluruh (paling tidak hampir) redaksi peristiwa bencana kedua kitab itu disebabkan oleh kedurhakaan dan ketidak taaatan umat-umat terdahulu. Kesamaan itu, paling tidak dikarenakan seluruh peristiwaperistiwa bencana atau kisah Nabi (Harun, 2019, hlm. 7) dan umat terdahulu yang disebutkan dalam alQur'an juga diceritakan dalam Alkitab, pun sebaliknya, walaupun disadari terdapat perbedaan-perbedaan substansial yang menonjol, tetapi kedua banyak berbicara suatu hal yang sama.

Menariknya lagi kedua agama ini, beranggapan bencana yang terjadi akhir-akhir ini tidak sama dengan peristiwa yang terjadi pada umat terdahulu dalam teks-teks kitab suci mereka. Islam atas kecintaan Nabi Muhammad sehingga tidak akan terjadi peristiwa bencana sedahsyat dulu, kecuali bersifat terbatas (tidak menyeluru) dan berdampak kepada siapapun tanpa pengecualian, sehingga disatu sisi sebagai cobaan (bagi yang taat) disis lain sebagai peringan (bagi yang tidak taat) untuk kembali ke jalan yang benar. Sedangkan bagi Kristen, peristiwa bencana dulu hanya ditimpakan kepada orang jahat, sehingga berbeda dengan bencana sekarang yang dialami oleh seluruh manusia baik dan jahat tanpa terkecuali, selain itu tidak ada peringatan dari Tuhan seperti peristiwa dulu. Dari dua poin ini kemudian, Alkitab memberikan bantuan berupa ayat-ayat penghibur korban dan bantuan kepada para penyembah Allah. 
Khazanah Theologia, Vol. 3 No. 1 (2021): 105-116

Bencana dan Tindakan Kepedulian Sosial dalam Keberagamaan: Studi Komparasi Kitab Suci al-Qur'an dan Alkitab

Abdul Qadri

Peristiwa-peristiwa bencana yang terjadi bagi kedua agama tersebut, menunjukkan pesan moral kemanusiaan berupa kepedualian sosial pasca bencana, kepedulian itu didorong oleh doktrin masingmasing agama. Bahkan nilai kemanusia itu "mendobrak" fanatisme umat pada agamanya dalam pluralisme agama dalam kaitannya korban bencana tersebut. Artinya, tidak melarangan untuk saling membantu, tolong menolong dan kerjasama dalam hal tersebut, setidaknya disebabkan oleh dua indikator yakni sama-sama ciptaan Tuhan dan sebagai agama yang rahmat. Pertama, Kritstiani menyakini bahwa setiap manusia merupakan keluarga besar Allah (Familia Dei)(Sumbulah \& Al Aluf, 2015, hlm. 48) demikian juga Islam sebagai saudara sekemanusiaan (Shihab, 2019, hlm. 74). Kedua, bahwa Islam adalah agama rahmat sama halnya Kristen dan Yahudi, kedua agama tersebut -terlepas dari perdebatan keasliannya-, Yahudi melalui Musa dan Kristen dengan Isa membawa ajaran yang rahmat (Ibnu 'Asyur, 1984, hlm. 167). Kepedulian sosial atau altruisme (Hadori, 2014, hlm. 3) itu, dibenarkan oleh John W. Santrock bahwa ada dalam setiap agama, yakni Islam, Kristen, Yahudi, Hindu dan Buddha (Jannah, 2016, hlm. 2).

Implikasi teoritis bencana dalam Islam dan Kristen menunjukkan ada kesamaan pesan dan misi bersama dari peristiwa-peristiwa bencana yang diabadikan dalam kedua kitab suci al-Qur'an dan Alkitab, bahwa fenomena bencana adalah tanggung jawab sosial bersama sebagai umat manusia dalam menyikapi dampak yang dialami masyarakat sekitar. Inilah yang disebut dengan spritual activism oleh A. Edwards dan Stephen G. Post artikelnya (Edwards \& Post, 2008), atau faith-based social activism (aktivisme sosial berbasis iman)(Ichwan, 2012, hlm. 28). Sehingga tidak ada penghalang dari perbedaan ras, budaya, suku, agama dan bangsa-bangsa untuk tujuan itu. Sedangkan implikasi kontekstualnya, melakukan upayaupaya sosial bagi korban bencana dalam ritus sosial keberagaamaan yang berdapak pada ekonomi, psikologi, emosional dan lain sebagainya, dengan pemberian dan penyaluran bantuan materil dan moril. Hal ini, sebagai kritik sosial masyarkat modern yang mendasarinya oleh kepentingan-kepentingan individualistik, materialistik dan oligarki, yang berakibat tidak mecapai tujuan hakiki.

Riset penelitian kebencanaan lintas agama pernah ditulis oleh Mundiroh Lailatul Munawaroh yakni antara agama Islam dan Buddah, hasil yang ditemukan bahwa kedua tidak jauh berbeda dalam hal penyebabnya. Konsep keseimbangan dari sistem kerja lima hukum alam sebagai kunci utama manusia dalam menjaga keseimbangannya (Munawaroh, 2011). Melanjutkan itu, sama halnya dengan agama Kristen, artinya ketiga agama tersebut setidaknya tidak jauh berbeda terkait "aktor" dan penyebab dari peristiwa bencana yang terjadi. Selain itu dari pemaparan sebelumnya, membuktikan baik agama Islam atau agama Kristen menuntut umatnya untuk tidak bersikap apatisme, egois atau indivisualistis dari kesengsaraan dan penderitaan para korban bencana. Sikap prinsip kepedulian sosial yang didorong keduanya, setidaknya tidak ada hubungannya dengan misi "Dakwah" atau "Misionaris". Karena kedua agama itu, tidak permah membeda-benadakan identitas agama dalam bantuan sosial beberapa argumen diatas cukup membuktikannya. Terlebih, Adler membuktikan kepedulian sosial sebagai sikap alamiah setiap masanusia (Marwing, 2016, hlm. 255), sehingga posisi agama itu membenarkan dan mendorong kesadaran gerakan aktivisme sosial humanitarian dalam masyarakat agama.

Untuk itu, bagi umat beragama baik Islam atau Kristen tidak lagi terus melakukan perdepat pada hal-hal yang justru memperkeruh kerukunan dan kedamaain bersama, akan tetapi ada hal yang bersifat substansial dan relevan dalam menjaga kerukun dan keharmonisan itu yakni kerjasama dalam kepedulian sosial bagi korban bencana yang terus bertambah seiring peristiwa-peristiwa bencana yang terus terjadi. Tanpa memandang status muslim atau kristiani atau agama-agama lain, juga tidak menjadi ajang rivalitas atas nama agama mereka masing-masing. Berkomitmen satu tujuan atas dasar persaudaraan manusia atau cinta kasih dalam mewujudkan kedamaian dan ketentraman bagi korban bencana yang memerlukan 
Khazanah Theologia, Vol. 3 No. 2 (2021): 105-116

Bencana dan Tindakan Kepedulian Sosial dalam Keberagamaan: Studi Komparasi Kitab Suci al-Qur'an dan Alkitab

Abdul Qadri

pertolongan semata, sebagai representasi dari pengamalan ajaran agama masing-masing. Sekali lagi, tidak untuk revalitas atau persaiangan institusi agama, melainkan sebagai momentum dalam membangun keharmonisan dan kerukunan antar agama.

\section{SIMPULAN}

Kitab suci al-Qur'an dan Alkitab banyak menceritakan kisah peristiwa-peristiwa bencana yang terjadi pada umat-umat terdahulu, peristiwa-peristiwa itu juga mirip-miri satu sama lain. Konsep bencana dari kedua kitab suci tersebut tidak berbeda jauh, bencana sebagai kehendak Tuhan disisi lain bencana juga terikat atas ulah prilaku manusia. Berdasarkan kedua kitab suci tersebut, peristiwa bencana terjadi merupakan bentuk dari akibat dari perbuatan durhaka dan bangkang dari umat terdahulu sehingga ditimpakan dengan berbagai macam bencana alam atau non-alam, seperti banjir, gempa bumi, wabah dan lain sebagainya. Peristiwa bencana yang terjadi akhir ini ternyata juga dialami oleh mereka yang taat, kedua kitab itu satu kata bahwa apa yang terjadi saat ini tidak sama seperti yang dialami oleh umat sebelumnya. Yang terpenting, dalam kaitannya bencana baik Islam atau Kristen sama-sama mengarahkan kepada sebuah pesan moral yaitu sikap kepedualian sosial bagi korban bencana atas dasa persaudaraan sesama manusia atau cinta kasih, tanpa memamdang identitas agama, artinya memberikan dan menyalurkan bantuan sosial bagi korban bencana adalah perintah tuhan yang meningkatkan keimanannya.

\section{REFERENSI}

al-Asqalani. (t.t.). Badzlul Ma'un fi Fadhl al-Tha'un. Riyad: Dar al-'Ashimah.

Al-Qurtubi, M. al-Ansari. (2006). Al-Jami'li Ahkam al-Qur'an (Vol. 7). Beirut: Muassasah al-Risalah. Ariansyah, A. (2020). Update Bencana di Indonesia 3 September 2020. Diambil 21 November 2020, dari BNPB website: https://bnpb.go.id/infografis/update-bencana-di-indonesia-3september-2020

Arqom Kuswanjono. (2012). Bencana Dalam Perspektif Filsafat Moral. Dalam Agama, Budaya, dan Bencana. Kajian Integratif Ilmu, Agama, dan Budaya (Ed: Indiyanto A \& Kuswanjono A). Bandung: Mizan.

Asparina, A., \& Farhani, K. R. S. (2020). Mitologi "Bencana adalah Azab" dalam Meme Media Sosial. Khazanah Theologia, 2(3), 164-177.

CAF. (2019). CAF World Giving Index Ten Years of Giving Trends October 2019. West Malling.

Cakra, P. (2020). Beriman Secara Autentik: Memahami Allah di Tengah Bencana Pandemi Covid-19. SOPHIA: Jurnal Teologi Dan Pendidikan Kristen, 1(1), 1-14.

Darmawan, D., Miharja, D., Waluyajati, R. S. R., \& Isnaeniah, E. (2020). Sikap Keberagamaan Masyarakat Menghadapi Wabah COVID-19. Religious: Jurnal Studi Agama-Agama Dan Lintas Budaya, 4(2), 115-124. https://doi.org/10.15575/rjsalb.v4i2.8596

Dictionary, C. (2015). Cambridge dictionaries online. Cambridge, UK: Cambridge University Press.

Edwards, M. A., \& Post, S. G. (2008). The love that does justice: Spiritual activism in dialogue with social science. Templeton: Unlimited Love Press.

Hadori, M. (2014). Perilaku Prososial (Prosocial Behavior); Telaah Konseptual Tentang Altruisme (Altruism) Dalam Perspektif Psikologi. LISAN AL-HAL: Jurnal Pengembangan Pemikiran Dan Kebudayaan, 8(1), 7-18.

Harun, A. (2019). Kisah Yusuf/Joseph Dalam Al-Qur'an Dan Alkitab. Jurnal Tafsere, 7(1), 31-44.

Hidayat, E. A. (2016). Iman di Tengah Penderitaan: Suatu Inspirasi Teologis-Biblis Kristiani. Melintas, 32(3), 285-308. https://doi.org/10.26593/mel.v32i3.2695.285-308. 
Khazanah Theologia, Vol. 3 No. 1 (2021): 105-116

Bencana dan Tindakan Kepedulian Sosial dalam Keberagamaan: Studi Komparasi Kitab Suci al-Qur'an dan Alkitab Abdul Qadri

Humaedi, M. A. (2015). Disaster Management Based on the Perspective of Inter-religious Connection and Local Wisdom. Analisa Journal of Social Science and Religion, 22(2), 213226.

I. Gusti Agung Paramita. (2018). Bencana, Agama Dan Kearifan Lokal. Dharmasmrti: Jurnal Ilmu Agama dan Kebudayaan, 18(1), 36-44. https://doi.org/10.32795/ds.v1i18.100

Ibnu 'Asyur. (1984). Tafsir al-Tahrir wa al-Tanwir (Vol. 17). Tunisia: Dar al-Tunisia.

Ichwan, M. N. (2012). Eko-teologi Bencana, Aktivisme Sosial, dan Politik Kemaslahatan. Dalam Agama, Budaya, dan Bencana. Kajian Integratif Ilmu, Agama, dan Budaya (Ed: Indiyanto A \& Kuswanjono A). Mizan, Bandung.

Jannah, M. (2016). “Konsep altruisme dalam perspektif Al Qur'an kajian integratif antara Islam dan psikologi" (Masters, Universitas Islam Negeri Maulana Malik Ibrahim). Universitas Islam Negeri Maulana Malik Ibrahim. Diambil dari http://etheses.uin-malang.ac.id/5595/

Marwing, A. (2016). Kritik Kepedulian Sosial Adler Dan Ikhlas Terhadap Perilaku Pro-Sosial Manusia Modern. Kontemplasi: Jurnal Ilmu-Ilmu Ushuluddin, 4(2), 253-276. https://doi.org/10.21274/kontem.2016.4.2.253-276

Mohammad Hasan Basri, Apriadi Ujiarso, \& Laily Hafidzah. (2012). Paradigma Eko-Filosofi Melacak Titik Temu Sains, Agama (islam) Dan Budaya (jawa) Dalam Memaknai, Mengelola, Dan Mengantisipasi Bencana. Dalam Agama, Budaya, dan Bencana. Kajian Integratif Ilmu, Agama, dan Budaya (Ed: Indiyanto A \& Kuswanjono A). Mizan, Bandung.

Muhlis, A. (2012). Bencana Alam Dalam Perspektif Al-Qur'an Dan Budaya Madura. KARSA: Journal of Social and Islamic Culture, 14(2), 175-186. https://doi.org/10.19105/karsa.v14i2.125

Munawaroh, M. L. (2011). "Bencana Alam dalam perspektif Islam dan Buddha" (Undergraduate, IAIN Sunan Ampel Surabaya). IAIN Sunan Ampel Surabaya. Diambil dari http://digilib.uinsby.ac.id/id/eprint/25252

Mustaqim, A. (2015). Teologi Bencana Dalam Perspektif Al-Qur'an. Nun : Jurnal Studi Alquran dan Tafsir di Nusantara, 1(1). https://doi.org/10.32459/nun.v1i1.9

Objantoro, E. (2016). Bencana Alam Ditinjau Dari Perspektif Teologi Alkitab. Jurnal Simpson: Jurnal Teologi dan Pendidikan Agama Kristen, 1(2). Diambil dari https://journal.sttsimpson.ac.id/index.php/Js/article/view/11

Pusat Bahasa (Indonesia). (2005). Kamus besar bahasa Indonesia: Edisi ketiga. Jakarta: Pusat Bahasa, Departemen Pendidikan Nasional: Balai Pustaka.

Setiawan, A. A., Johan. (2018). Metodologi penelitian kualitatif. Yogyakarta: Jejak Publisher.

Shihab, M. Q. (2019). Wasathiyyah Wawasan Islam tentang Moderasi Beragama. Jakarta: Lentera Hati.

Shihab, M. Q. (2020). Islam \& Kebangsaan: Tauhid, Kemanusiaan, dan Kewarganegaraan. Jakarta: Lentera Hati Group.

Siahaya, J., Siahaya, K. M., \& Rinukti, N. (2020). Tuhan Ada di Mana-mana: Mencari Makna bagi Korban Bencana di Indonesia. KURIOS (Jurnal Teologi Dan Pendidikan Agama Kristen), 6(1), 103-113. https://doi.org/10.30995/kur.v6i1.147

Singgih, E. G. (1999). Dunia yang bermakna: Kumpulan karangan tafsir Perjanjian Lama. Jakarta: Persetia.

Sumbulah, U., \& Al Aluf, W. (2015). "Fluktuasi relasi Islam Kristen di Indonesia: Pendekatan sosiohistoris". Malang: UIN Maliki Press. Diambil dari http://repository.uin-malang.ac.id/456/

Suprapto, S., \& Huda, M. (2020). Religiositas di Tengah Bencana Gempa Bumi Lombok-Indonesia. Religious: Jurnal Studi Agama-Agama Dan Lintas Budaya, 4(2), 93-102.

Suryadilaga, M. A. (2005). Metodologi Ilmu Tafsir. Yogyakarta: Teras.

Tefbana, A., \& Rantung, D. A. (2020). Perspektif Pendidikan Agama Kristen Terhadap Teologi Kebencanaan Dan Peran Gereja Dalam Menghadapi Pendemic Covid 19. JURNAL LUXNOS, 6(1), 72-88. https://doi.org/10.47304/jl.v6i1.32

Wijaya, R. T., Azeharie, S. S., \& Pribadi, M. A. (2019). Fenomena Ciong Pada Budaya Penganut Konghucu. Koneksi, 2(2), 540-547. 
Khazanah Theologia, Vol. 3 No. 2 (2021): 105-116

Bencana dan Tindakan Kepedulian Sosial dalam Keberagamaan:

Studi Komparasi Kitab Suci al-Qur'an dan Alkitab

Abdul Qadri

Yulianti, R. T. (2016). Menyikapi Musibah Alam: Suatu Upaya Meluruskan Kegelisahan Teologi. UNISIA, 1(56), 158-169. https://doi.org/10.20885/unisia.vol28.iss56.art6

Zuchdi, D. (2011). Pendidikan karakter dalam perspektif teori dan praktik. Yogyakarta: UNY Press. 